\title{
Effects of canola and soya lecithins compared with canola oil and seed on performance, carcass quality and body fat composition of growing bulls
}

\author{
H.-R. Wettstein, M. Kreuzer', F. Sutter and M.R.L. Scheeder
}

Institute of Animal Sciences, Animal Nutrition

ETH Zurich, ETH Centre/LFW B56

CH-8092 Zurich. Switzerland

(Received 27 April 2000; accepted 4 October 2000)

\section{ABSTRACT}

Fattening bulls (six per treatment) were fed rations supplemented either with raw or modified (deoiled and deoiled/partially hydrolyzed) canola lecithins or deofled soya lecithin at $30 \mathrm{~g} / \mathrm{kg}$ DM on a fatty acid basis. These were also compared with rations supplemented with canola oil or crushed canola seed. No differences occurred in liveweight gain, fecd conversion efficiency or carcass traits. The elevated proportions of odd-chain fatty acids found in the body fats indicate that lecithins might affect rumen fermentation less than oils. Trends in rumen flujd ammonia concentration suggest a reduced ruminal protcin degradation with lecithins. Polyenoic fatty acids were highest with canola oil in kidney fat and intermuscular fat. The fatty acid profile of body fat depended more on the origin of lecithin (canola vs soyabean) than on the exchange of oil or technological lecithin modifications. Consequently, canola lecithins can replace canola oil without greater effects on growth and carcass yield and only minor variation in carcass fat composition.

KEY WORDS: lecithin, canola, fatty acids, performance, body fat composition, becf bulls

\section{INTRODUCTION}

Plant lecithins are obtained as by-products during the refining process of raw plant oils. The term 'lecithins', as used for these by-products, covers complex

\footnotetext{
' Corresponding author
} 
mixtures mainly of different phospholipids but also of other polar substances and, if not further processed, residual triglyccrides (Pardun, 1988). In contrast to oils, lecithins are dispersible in water (Pardun, 1988) and contain a fraction that slowly disappears in the rumen (Jenkins et al., 1989) presumably because different enzymes are nccessary to hydrolyze phospholipids and triglycerides (Harfoot, 1981). Consequently, attachment of plant lecithins to feed particles or rumen microbes might be less pronounced than with oils and the release of the fatty acids (FA) could be slower from lecithins, both resulting in less adverse effects on rumen fermentation than with corresponding oils as was shown in vitro (Wettstein et al., 2000). As far as the direct adverse effects of lipids against rumen microbes are concerned, this also depends on specific FA. The FA composition of lecithins is quite variable and substantially differs when the lecithins originate from different plants. Until now, most investigations on lecithins in ruminant nutrition focussed on soya lecithins (c.g., Yoon et al., 1986; Jenkins et al., 1989; Jenkins and Fotouhi, 1990; Lough et al., 1991, 1992). Nowadays, considerable amounts of canola lecithins are also available as potential feedstuffs, but data on the actual feeding value of any type of canola lecithin for growing ruminants are still lacking. Canola lecithins might suppress rumen cellulolytes even less than soya lecithins because of their lower content of linoleic acid (Nagaraja et al., 1997). Additionally, the undesired residual oil can be removed and the specific properties of lecithins can be enhanced by new processing technologies. Such products were shown in vitro to be particularly promising in terms of reduced perturbation of rumen fermentation (Wettstein et al., 2000). Using canola lecithins instead of oil as the only lipid supplement was furthermore found to reduce the in vitro ruminal degradation of feed protein (Wettstein et al.. 2000). possibly due to the amphiphatic (i.c., polar - apolar) properties of the lecithins (Jenkins et al.. 1989). This might increase the amount of absorbable protein entering the duodenum.

The objective of the present study was to investigate the effects of differently processed canola lecithins and deoiled soya lecithin in the dict of growing bulls in comparison with canola oil and seed. Using raw and modified lecithins should make it possible to identify the effects of particular physical and chemical propertics. In order to be able to determine any lecithin effects on duodenal protein supply, diets were designed to contain slightly ( $10 \%$ ) less calculated duodenally absorbable protein (FAG, 1994) than recommended. Apart from fattening performance and carcass quality, focus was put on the effects on body fat composition since lecithins of different origin (canola and soyabean) and from different processing techniques clcarly differ in FA composition. The data obtained should provide the basis for the possible application of lecithins in fecding practice as an energy source and/or as a mode to selectively modify body fat composition. 


\section{MATERIAL AND METHODS}

Design of the experiment and of the diets

The present experiment consisted of six different dietary treatment groups all supplemented with $30 \mathrm{~g} / \mathrm{kg}$ dry matter (DM) of lipids calculated as triglyceride equivalents. Three different canola lecithins and deoiled soya lecithin ( $\mathrm{SL}_{\mathrm{j}}$ ) were examined. The canola lecithins formed a series with increasing dispersibility in water: raw canola lecithin $\left(\mathrm{CL}_{\mathrm{r}}\right)$, deoiled canola lecithin $\left(\mathrm{CL}_{\mathrm{d}}\right)$ and deoiled/partially hydrolyzed canola lecithin $\left(\mathrm{CL}_{\mathrm{dit}}\right)$. These lecithins were opposed to canola oil (CO) and crushed whole canola seed (CS). No unsupplemented control was used sinec due to the lower energy content of the respective concentrate a different ratio of forage to concentrate would have been necessary. Whole canola seed was offered in a crushed form, which is necessary for sufficient digestion of the seed, but still provides the lipids in a partially rumen protected form (Drochner and Heller, 1996). Crushed canola seed, supplied at the proportion used in the present study, was shown earlier to be suitable for fattening bulls (Kreuzer et al.. 1985: Sutter et al., 2000). All six lipid supplements werc provided by Lucas Meyer GmbH and Co (Hamburg, Germany) with all of the canola products originating from one batch of canola seed.

The lipids were included at proportions equivalent to $100 \mathrm{~g}$ triglycerides (calculated from fatty acid methyl esters) per $\mathrm{kg}$ in the concentrates, with the concentrates making up proportionately 0.3 of total feed dry matter. Table 1 gives the ingredient composition of the concentrates used for the starting and finishing periods of fattening. Because of the use of urca in the finisher concentrates, these were supplemented with $\mathrm{S}, \mathrm{Cu}, \mathrm{Zn}$ and $\mathrm{Mn}$ as recommended (FAG, 1994). Both types of concentrate contained the same proportions of the lipid supplements and mainly differed in the ratio of protein and energy in order to cope with the agc-dependent changes in requirements.

All complete dicts were composed to meet the Swiss feeding recommendations (FAG, 1994). They consisted of maize silage, hay, concentrate and additional potato protein. The avcrage composition as illustrated in Table 2 varied with age. The individual rations were adapted weekly to the actual liveweight (extrapolated from two-weekly measurements) for the individual animals to fulfill the recommendations of energy and protein for expected average daily gains of $1.2 \mathrm{~kg} / \mathrm{d}$ (FAG, 1994). For this purpose, also the extra amount of potato protein (Table 2) was gradually reduced during fattening to account for the continuously decreasing protein requirements relative to the energy demand. The supply of absorbable protein at the duodenum (APD, corresponding to the French PDI) was limited to $91 \%$ of the tabulated values in order to promote growth responses to additional APD as expected from lecithin action in the rumen. The 
diets were similar in calculated contents of net energy (NEV) according to the Swiss feeding standards (FAG, 1994) and of metabolisable energy (ME) according to the German feeding standards (DLG, 1997).

TABLE 1

Ingredients used in the concentrates, $\mathrm{g} / \mathrm{kg} \mathrm{DM}$

\begin{tabular}{|c|c|c|c|c|c|c|}
\hline Treatment/lipid & $\begin{array}{c}\text { Canola } \\
\text { oil } \\
\text { CO }\end{array}$ & $\begin{array}{c}\begin{array}{c}\text { Canola } \\
\text { seed } \\
\text { crushed }\end{array} \\
\text { CS }\end{array}$ & $\begin{array}{c}\text { Raw } \\
\text { canola } \\
\text { lecithin } \\
\text { CL }\end{array}$ & $\begin{array}{c}\text { Deoiled } \\
\text { canola } \\
\text { lecithin }\end{array}$ & $\begin{array}{l}\text { Deoiled/ } \\
\text { hydrolysed } \\
\text { canola } \\
\text { lecithin } \\
\mathrm{CL}\end{array}$ & $\begin{array}{c}\text { Deoiled } \\
\text { soya } \\
\text { lecithin }\end{array}$ \\
\hline \multicolumn{7}{|l|}{ Period $1(<300 \mathrm{~kg} \mathrm{LW})$} \\
\hline canola oil & 100 & - & - & & & - \\
\hline canola seed & - & 227 & - & - & - & - \\
\hline canola lecithin $(\mathrm{CL})$ raw & - & - & 161 & - & - & - \\
\hline CL deoiled & - & - & - & 200 & - & - \\
\hline CL deoiled/hydrolysed & - & - & - & - & 200 & - \\
\hline soya lecithin deoiled & - & - & - & - & - & 200 \\
\hline barley & 200 & 202 & 122 & 131 & 140 & 121 \\
\hline straw meal & 176 & 186 & 168 & 178 & 177 & 178 \\
\hline soyabean meal & 471 & 244 & 502 & 386 & 374 & 403 \\
\hline potato protein & - & 94 & - & 58 & 62 & 51 \\
\hline urea & 6 & - & - & - & - & - \\
\hline $\mathrm{NaCl}$ & 1 & 1 & 1 & 1 & 1 & 1 \\
\hline mineral premix & 46 & 46 & 46 & 46 & 46 & 46 \\
\hline \multicolumn{7}{|l|}{ Period 2 (> $300 \mathrm{~kg} \mathrm{LW})$} \\
\hline canola oil & 100 & - & - & 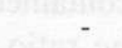 & - & - \\
\hline canola seed & - & 227 & - & - & - & - \\
\hline CL raw & - & - & 161 & - & - & - \\
\hline CL deoiled & - & - & - & 200 & - & - \\
\hline CL deoiled/hydrolysed & - & - & - & 2- & 200 & - \\
\hline soya lecithin deoiled & - & - & - & - & - & 200 \\
\hline barley & 590 & 453 & 512 & 433 & 434 & 434 \\
\hline straw meal & 80 & 96 & 71 & 88 & 88 & 87 \\
\hline soyabean meal & 122 & 129 & 154 & 181 & 181 & 181 \\
\hline urea & 51 & 38 & 45 & 41 & 40 & 41 \\
\hline $\mathrm{Na}_{2} \mathrm{SO}_{4}(138 \mathrm{~g} \mathrm{~S} / \mathrm{kg})$ & 15 & 15 & 15 & 15 & 15 & 15 \\
\hline mineral premix & 40 & 40 & 40 & 40 & 40 & 40 \\
\hline trace element premix ${ }^{2}$ & 2 & 2 & 2 & 2 & 2 & 2 \\
\hline
\end{tabular}

per kg: Ca, $170 \mathrm{~g} ; \mathrm{P}, 50 \mathrm{~g} ; \mathrm{Mg}, 30 \mathrm{~g} ; \mathrm{Na}, 40 \mathrm{~g}$; vit. A, 1,000,000 IU; vit. $\mathrm{D}_{3}, 220,000 \mathrm{IU}$; vit. E, $1,500 \mathrm{mg}$

2 per kg: $\mathrm{Cu}, 6.8 \mathrm{~g} ; \mathrm{Zn}, 34.1 \mathrm{~g} ; \mathrm{Mn}, 50 \mathrm{~g}$ 
TABLE 2

Average composition of the complete diets within the whole fattening period as well as fatty acid (FA) composition of the lipids supplemented

\begin{tabular}{|c|c|c|c|c|c|c|}
\hline & $\mathrm{CO}$ & $\mathrm{CS}$ & $\mathrm{CL}_{\mathrm{r}}$ & $\mathrm{CL}_{\mathrm{d}}$ & $\mathrm{CL}_{\mathrm{w} \mathrm{w}_{1}}$ & $\mathrm{SL}_{\mathrm{d}}$ \\
\hline \multicolumn{7}{|c|}{$\begin{array}{l}\text { Ingredient composition of the } \\
\text { complete diets, } g / \mathrm{kg} \mathrm{DM}\end{array}$} \\
\hline maize silage & 597 & 591 & 591 & 589 & 590 & 594 \\
\hline meadow hay & 98 & 99 & 99 & 100 & 100 & 99 \\
\hline concentrate & 296 & 300 & 301 & 302 & 300 & 298 \\
\hline type for period 1 & 79 & 89 & 88 & 82 & 94 & 77 \\
\hline type for period 2 & 217 & 211 & 213 & 220 & 206 & 221 \\
\hline extra potato protein & 9 & 10 & 9 & 9 & 10 & 9 \\
\hline \multicolumn{7}{|c|}{ Nutrient composition of the diets, $\mathrm{g} / \mathrm{kg} \mathrm{DM}$} \\
\hline$M E^{\prime}, \mathrm{MJ} / \mathrm{kg} \mathrm{DM}$ & 11.1 & 11.0 & 11.2 & 11.2 & 11.2 & 11.2 \\
\hline NEV $. \mathrm{MJ} / \mathrm{kg} \mathrm{DM}$ & 7.03 & 7.03 & 7.05 & 7.04 & 7.04 & 7.03 \\
\hline crude protcin & 147 & 144 & 150 & 149 & 152 & 147 \\
\hline $\mathrm{APD}^{2}$ & 88 & 89 & 89 & 89 & 89 & 88 \\
\hline organic matter & 947 & 945 & 945 & 942 & 943 & 943 \\
\hline ether extract & 46.8 & 53.7 & 54.1 & 55.5 & 52.5 & 53.6 \\
\hline total FA & 47.4 & 46.0 & 45.9 & 50.8 & 49.0 & 49.3 \\
\hline \multicolumn{7}{|l|}{$\mathrm{FA}, \mathrm{g} / \mathrm{kg}$ total FA } \\
\hline $\mathrm{C} 16: 0$ & 93 & 93 & 113 & 123 & 131 & 178 \\
\hline $\mathrm{C} 18: 0$ & 20 & 20 & 19 & 16 & 18 & 36 \\
\hline C20:0 & 6 & 6 & 4 & 3 & 3 & 3 \\
\hline $\mathrm{C} 22: 0$ & 5 & 6 & 5 & 4 & 4 & 7 \\
\hline C:8:1 & 457 & 449 & 409 & 393 & 381 & 128 \\
\hline$C 20: 1 n-9$ & 12 & 13 & 2 & 3 & 3 & 2 \\
\hline$C 22: \ln -9$ & 5 & 9 & 2 & 1 & 1 & 1 \\
\hline C $18: 2 n-6$ & 302 & 298 & 358 & 379 & 381 & 550 \\
\hline C18:3n-3 & 92 & 98 & 79 & 69 & 70 & 86 \\
\hline \multicolumn{7}{|c|}{ Composition of the lipid supplements } \\
\hline $\begin{array}{l}\text { total } \mathrm{FA}^{\prime}, \mathrm{g} / \mathrm{kg} \\
\mathrm{FA}, \mathrm{g} / \mathrm{kg} \text { total } \mathrm{FA}\end{array}$ & 1000 & 423 & 581 & 556 & 529 & 540 \\
\hline C.16:0 & 46 & 47 & 78 & 98 & 109 & 183 \\
\hline C.18:0 & 17 & 17 & 15 & 12 & 14 & 42 \\
\hline $\mathrm{C} 20: 0$ & 7 & 7 & 4 & 2 & 2 & 2 \\
\hline $\mathrm{C} 22: 0$ & 4 & 4 & 3 & 2 & 2 & 6 \\
\hline C.18:1 & 594 & 577 & 520 & 477 & 463 & 73 \\
\hline $\mathrm{C} 20: \ln -9$ & 16 & 18 & 2 & 3 & 3 & 1 \\
\hline $\mathrm{C} 22: 0 \mathrm{n}-9$ & 6 & 14 & 2 & 1 & 1 & 1 \\
\hline C.18:2n-6 & 208 & 207 & 296 & 340 & 340 & 601 \\
\hline C $18: 3 n-3$ & 97 & 107 & 76 & 62 & 62 & 88 \\
\hline
\end{tabular}

1 metabolisable cnergy calculated according to tabulated values (DLG, 1997)

2 calculated as net energy meat (NEV) and absorbable protein at the duodenum (APD) from tabulated values (FAG, 1994)

3 calculated as triglyceride equivalents 
Animals and experimental techniques

At the start of the expcriment 36 Brown Swiss bulls weighing on average $170 \mathrm{~kg}$ were allocated to groups of six animals per pen. Each animal within a pen received a different ration out of the six treatments. The fattening period was subdivided into a starter period (period 1) until the animals reached $300 \mathrm{~kg}$ livewcight and the subsequent finisher period (period 2) until slaughter, separated by the change of concentrate type. Pens had two areas, one with deep litter in the rear part, and one with a concrete floor in the front part at the fceding places. Tap water was continuously available. Each bull had access to only one feeding placc by passing a special door (American Calan Inc., Northwood, NH, USA) equipped with a transponder for electronic identification control (Westfalia Separator, Oclde, Germany). The total rations were replenished two times per day. Refusals were recorded separately for each compound on four days per week. Forage was sampled twice per week and analyzed for dry matter content. Part of the samples were dried in an oven at $60^{\circ} \mathrm{C}$ and pooled over two weeks. Concentrates were sampled once per weck and pooled over four wecks for compositional analyses. The bulls were weighed every second week. The fattening period lasted until $500 \mathrm{~kg}$ liveweight was reached on average for all animals of one pen. With this procedure, the avcrage duration of the fattening period was exactly the same for all treatments. Slaughter was performed at a commercial slaughter plant. Weights were measured before transport and 45 min p.m. (hot carcass weights). At slaughter $200 \mathrm{ml}$ of rumen fluid were collected directly from the rumen. Kidney fat was weighed and samples of kidney fat were taken. Carcass grading was carricd out according to the Swiss beef classification grid (GSF, 1994), which is similar to the EUROP grading system of the European Union. Samples of the M. longissimus dorsi (LD) for analysis of intramuscular fat and of the intermuscular fat between LD and $M$. spinalis et semispinalis dorsi et cervicis were obtained from the $8 \mathrm{th}$ and the 9 th rib $18 \mathrm{~h}$ subsequent to slaughter. The LD sample was homogenized with a Moulinette ${ }^{\text {in }} \mathrm{S}$ food mixer (GROUP Moulinex, Paris, France) and vacuum sealed before freezing.

\section{Chemical and statistical analyses}

The nutrient composition of the feed ingredients was determined by standard procedures (Naumann and Bassler, 1997). In rumen fluid, $\mathrm{pH}$ and ammonia were measured with a pH meter (model 713, Metrom, Herisau, Switzerland) equipped with the respective electrodes. Bürker counting chambers (Blau Brand, Wertheim, Germany) were used for enumeration of ciliates (depth $0.1 \mathrm{~mm}$ ) and bacteria (depth $0.02 \mathrm{~mm}$ ). Volatile fatty acid concentrations in rumen fluid were analyzed by gas chromatography (GC Star $3400 \mathrm{CX}$, Varian, Palo Alto, CA, USA) according to Tangerman and Nagengast (1996). 
Lipids were extracted with hexane/isopropanol 3:2(v/v). In samples of feed ingredients, cxtraction was done in an Accelerated Solvent Extractor (ASE 200. Dionex Corporation, Sunnyvale, CA, USA). Body fat tissues were homogenized in the solvent mixture and stored for $1 \mathrm{~h}$ before being filtered. FA methyl esters (FAME) were prepared according to IUPAC (1987). Two different analyses on gas chromatographs (HP 5890 and HP 6890. Hewlett Packard, Wilmington, DE, USA) were performed using Supelcowax ${ }^{\mathrm{TM}} 10$ and 2560 capillary columns (Supelco, Bellefonte. PA, USA), respectively, in order to separate (i) FA according to chain length and number of double bonds and (ii) C $18: 1$ isomers (only in body fat samples). Total FA contents of the feed ingredients and LD samples were determined using triundecanin as the internal standard, which was given into the extraction cell prior to extraction. Canola oil was used as the reference fat to determine the response factor. $\mathrm{C} 18: 1$ cis and trans isomer percentage (ii) was related to total C18:1 (i). Without previous thin layer chromatography it is not possible to separate all $\mathrm{C} 18: 1$ isomers and $\mathrm{C} 18: 1$ trans isomers with a double bond in position $\leq \omega 6$ from certain cis isomers (Precht and Molkentin, 1995). Thus, only the trans isomers with double bonds in positions $\omega 13-\omega 7$ were taken into account for the calculation of total trans C18:1. With this simplification the effective content of C18:1 trans isomers was presumably slightly underestimated and vice versa for the cis isomers. The melting behaviour of the intermuscular fat was analyzed by differential scanning calorimetry (DSC 2010, TA Instruments, Alzenau, Germany) as described by Casutt et al. (1999).

Statistical evaluation was carried out by analysis of variance regarding diet and pen as fixed effects applying the GLM-procedure of SAS (1996). The pen effect includes the effect of slaughter day. Multiple comparison of the least square (LS) means was done with the Tukcy-Kramer method applying $\mathrm{P}<0.05$.

\section{RESULTS}

One bull from the canola oil treatment had to be removed due to problems with severe pneumonia. Feed intake increased from $3.8 \pm 0.5$ to $8.3 \pm 0.4 \mathrm{~kg}$ DM per day on average of all groups during the experiment. Daily DM intake was slightly lower with the canola seed diet than with the other diets $(\mathrm{P}<0.1)$ and no significant group differences were found in daily liveweight gain and feed conversion efficiency (Table 3). The same is true for energy and protcin cxpenditure per $\mathrm{kg}$ weight gain. Also final livewcight, hot carcass weight and dressing percentage were similar in all six treatments. Conformation, fatness scores and proportion of kidney fat did not significantly differ among groups, but fatness scores were numerically lower in the raw canola lecithin and in the soya lecithin treatment. 
Rumen fluid $\mathrm{pH}$ ranged in all diets at a similarly high level (Table 3). There was a non-significant trend in rumen fluid ammonia concentration with lower values being found in all of the lecithin-supplemented diets. Neither total volatile fatty acid (VFA) concentrations nor individual VFA proportions differed signifi-

TABLE 3

Fattening performance, carcass characteristics and rumen fluid properties'

\begin{tabular}{|c|c|c|c|c|c|c|c|c|}
\hline & $\mathrm{CO}$ & $\mathrm{CS}$ & $\mathrm{CL}_{\mathrm{r}}$ & $\mathrm{CL}_{\mathrm{d}}$ & $\mathrm{CL}_{\mathrm{dh}}$ & $\mathrm{SL}_{\mathrm{d}}$ & SEM & $P$ \\
\hline ry ma & 6.49 & 6 & 6.46 & 6.50 & 6.53 & 6.61 & 0.069 & 0.062 \\
\hline Gains, & 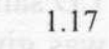 & 4 & 18 & .21 & 1.21 & 1.21 & 0.046 & 0.908 \\
\hline \multicolumn{9}{|c|}{ Feed conversion efficiency, per kg gain } \\
\hline dry matter, $\mathrm{kg}$ & 5.56 & 5.59 & 5.54 & 5.39 & 5.43 & 5.51 & 0.201 & 0.985 \\
\hline $\mathrm{ME}, \mathrm{MJ}$ & 61.9 & 61.3 & 62.0 & 60.3 & 60.8 & 61.6 & & 0.994 \\
\hline $\mathrm{NEV}, \mathrm{MJ}$ & 39.1 & 39.3 & 39.1 & 37.9 & 38.2 & 38.8 & 1.42 & 0.987 \\
\hline crude protein, $\mathrm{g}$ & 821 & 808 & 828 & 802 & 818 & 810 & 30.9 & 0.992 \\
\hline APD, $\mathrm{g}$ & 492 & 498 & 492 & 475 & 479 & 484 & 20.0 & 0.974 \\
\hline \multicolumn{9}{|l|}{ Carcass characteristics } \\
\hline final liveweight, $\mathrm{kg}$ & 504 & 494 & 509 & 513 & 515 & 515 & 12.9 & 0.882 \\
\hline hot carcass weight, $\mathrm{kg}$ & 270 & 266 & 274 & 276 & 278 & 278 & 7 & 0.858 \\
\hline of carcass & 2.75 & 2.45 & 2.03 & 2.24 & 2.41 & 2.26 & 57 & 0.560 \\
\hline dressing percentage & 53.6 & 53.8 & 54.0 & 53.7 & 53.9 & 54.0 & 0. & 0.979 \\
\hline ation score ${ }^{2}$ & 2.92 & 2.94 & 2.84 & 2.89 & 2.76 & 2.95 & 9 & 0.950 \\
\hline fatness score ${ }^{3}$ & 2.26 & 2.09 & 1.78 & 2.41 & 2.41 & 1.57 & 0.236 & 0.106 \\
\hline \multicolumn{9}{|c|}{ Rumen fluid properties at slaughter } \\
\hline $\mathrm{pH}$ & 6.95 & 6.7 & 6.90 & 6.74 & 6.94 & 6.73 & 0.099 & 0.449 \\
\hline $\begin{array}{l}\mathrm{NH}_{3}, \mathrm{mmol} / \mathrm{l} \\
\text { volatile fatty acids }\end{array}$ & 7.09 & 5.65 & 4.60 & 4.88 & 5.02 & 3.98 & 0.946 & 0.375 \\
\hline total, $\mathrm{mmol} / \mathrm{l}$ & 69.9 & 77.9 & 73.2 & 73.9 & 72.9 & 76.9 & 4. & 0.840 \\
\hline \multicolumn{9}{|c|}{ proportion of individual volatile fatty acids, $\mathrm{mmol} / \mathrm{mol}$} \\
\hline acetate & 778 & 762 & 772 & 761 & 766 & 760 & 21.2 & 0.991 \\
\hline propionate & 130 & 138 & 134 & 128 & 140 & 139 & 14.7 & 0.991 \\
\hline iso-butyrate & 82 & 83 & 98 & 94 & 81 & 81 & 1.0 & 0.733 \\
\hline butyrate & 55 & 61 & 52 & 68 & 56 & 60 & 7.5 & 0.717 \\
\hline iso-valerate & 12 & 14 & 14 & 16 & 12 & 14 & 1.4 & 0.304 \\
\hline valerate & 17 & 17 & 19 & 17 & 18 & 19 & 1.6 & 0.929 \\
\hline acetate:prop & 6.95 & 6.99 & 6.19 & 6.71 & 6.48 & 6.83 & 0.841 & 0.984 \\
\hline bacteria, $10^{10} / \mathrm{ml}$ & 2.33 & 2.24 & 2.36 & 2.19 & 2.14 & 2.41 & 0.186 & 0.890 \\
\hline ciliates, $10^{5} / \mathrm{ml}$ & 3.25 & 4.80 & 1.91 & 2.38 & 3.38 & 3.93 & 0.939 & 0.326 \\
\hline
\end{tabular}

SEM $=$ standard error of the means. LS means by treatment, $n=6$

2 conformation score: 1 (very weak) to 5 (very pronounced) according to GSF (1994)

3 fatness score: 1 (low) to 5 (high) according to GSF (1994) 
cantly between the diets. The VFA profile was of a kind that is typical of foragebased diets. The number of bacteria in rumen fluid was similar for all the diets and no significant group differences were found for ciliate counts despite the numerically high difference between diets.

The intramuscular fat contents as measured in LD muscle (here determined as total FA content) were gencrally low (Table 4). They showed a weak trend towards lower values with raw canola oil and deoiled soya lecithin that resembled the trend in fatness scores. Also no significant differences were found in the proportions of total saturated, monoenoic and polycnoic FA in intramuscular fat. This is also the case for the major saturated FA, C16:0 and C18:0, whereas the proportions of saturated odd-numbered FA (C15:0, $\mathrm{C} 17: 0$ and $\mathrm{C} 19: 0)$ was significantly higher with deoiled and deoiled/hydrolyzed canola lecithin than with canola oil and canola seed. The same trend was observed with $\mathrm{C} 17: 1$ as odd-numbered monoenoic FA. The proportion of $\mathrm{C} 20: 0$ was significantly higher with the canola oil than with the soya lecithin diet, with intermediate values for all other groups. The proportion of total $\mathrm{C} 18: 1 \mathrm{cis}$ and $\mathrm{C} 18: 1$ trans was similar for all dicts. However, C18:1n-6-cis proportion was significantly highest with the soya lecithin diet which was counterbalanced by respectively lower $\mathrm{C} 18: \ln$-12-trans proportions. With canola oil, canola seed as well as deoiled canola lecithin there was a trend for a higher $\mathrm{C} 20: \ln -9$ proportion in LD. In none of the individual polyenoic FA significant differences in proportion among the diets were found. However, the soya lecithin treatment showed the numerically highest content of polyenoic FA.

Diet effects on the composition of intermuscular fat as wcll as on kidney fat were similar (Tables 5 and 6). No significant differenees between diets in the proportions of total saturated or monoenoic FA were found in either intermuscular or kidney fat. In both fats, the proportion of total polyenoic FA was significantly higher with the use of canola oil (and canola seed) than with the deoiled canola lecithin, which is in some contrast to the findings in intramuscular fat. Furthermore, in kidney fat a significant $(\mathrm{P}<0.05)$ treatment effect on the proportion of $\mathrm{C}$ 16:0 occurred, but no significant differences were identified between individual diets by multiple comparison among means. The proportion of $\mathrm{C}$ 1 6:0 in intermuscular fat and kidney fat showed a trend to be highest with the deoiled soya lecithin dict. In both fats the proportion of C20:0 was significantly lower with deoiled/ hydrolyzed canola lecithin and deoiled soya lecithin than with canola oil or canola seed. Highly significant differences were once again found in both body fats in the proportion of the saturated odd-numbered FA, with the highest values measured for the deoiled and the deoiled hydrolyzed canola lecithin. Values for raw canola lecithin and deoiled soya lecithin were intermediate and lowest for canola oil and canola seed. Trends in C17:1 were similar. Proportions of C18:1n-7-cis were lowest with the deoiled canola lecithin diet, and significantly differed from the canola oil diet in both fats and from the canola seed diet in intermuscular fat. With 
deoiled soya lecithin, the proportions of C18: $\ln -6$-cis and C18: $\ln -2$-trans/n-4-cis were significantly highest. Proportions of $\mathrm{C} 20: 1$ were significantly higher with canola oil followed by canola seed, and was lowest with all deoiled lecithins in both body fats. Proportions of C18:2n-6 were lowest in both fats when deoiled

TABLE 4

Intramuscular fatty acid (FA) content and composition of M. longissimus dorsi ${ }^{1}$

\begin{tabular}{|c|c|c|c|c|c|c|c|c|}
\hline & $\mathrm{CO}$ & $\mathrm{CS}$ & $\mathrm{CL}_{\mathrm{r}}$ & $\mathrm{CL}_{\mathrm{d}}$ & $\mathrm{CL}_{\mathrm{d}+1}$ & $\mathrm{SI}_{i 1}$ & SEM & $\mathrm{P}$ \\
\hline FA content, $\mathrm{g} / \mathrm{kg}$ & 19.3 & 19.7 & 16.2 & 17.3 & 18.1 & 14.3 & 2.55 & 0.694 \\
\hline \multicolumn{9}{|l|}{ FA profile, $\mathrm{g} / \mathrm{kg}$ total $\mathrm{FA}$} \\
\hline saturated $\mathrm{F} \Lambda$ & 468.8 & 469.2 & 473.2 & 464.4 & 471.1 & 463.7 & 10.45 & 0.985 \\
\hline $\mathrm{C} 14: 0$ & 18.9 & 19.4 & 18.3 & 17.0 & 18.6 & 17.1 & 1.29 & 0.711 \\
\hline $\mathrm{C} 16: 0$ & 209.7 & 213.8 & 209.1 & 198.1 & 204.7 & 207.4 & 5.69 & 0.515 \\
\hline $\mathrm{C} 18: 0$ & 219.8 & 216.0 & 224.2 & 226.2 & 224.6 & 218.2 & 7.77 & 0.924 \\
\hline $\mathrm{C} 20: 0$ & $2.1^{4}$ & $1.9^{\text {air }}$ & $1.7^{\text {the }}$ & $1.8^{\mathrm{abc}}$ & $1.6^{b c}$ & $1.4^{c}$ & 0.09 & 0.001 \\
\hline odd numbered ${ }^{2}$ & $14.7^{\mathrm{c}}$ & $15.2^{\mathrm{hc}}$ & $16.5^{\mathrm{ubc}}$ & $17.8^{: \text {:h }}$ & $18.2^{:}$ & $15.9^{\text {shic }}$ & 0.62 & 0.004 \\
\hline monoenoic FA & 428.7 & 433.2 & 413.5 & 423.5 & 419.8 & 411.5 & 10.40 & 0.667 \\
\hline $\mathrm{C} 16: 1$ & 22.8 & 24.3 & 23.1 & 23.9 & 23.7 & 25.2 & 1.09 & 0.705 \\
\hline $\mathrm{C} 17: 1$ & $6.4^{\mathrm{h}}$ & $7.3^{\text {ab }}$ & $7.6^{\mathrm{ah}}$ & $8.8^{\mathrm{u}}$ & $7.9^{\mathrm{ab}}$ & $7.4^{\mathrm{ab}}$ & 0.44 & 0.034 \\
\hline total $\mathrm{C} 18: 1$ & 394.0 & 396.0 & 378.2 & 385.6 & 383.6 & 374.6 & 9.92 & 0.632 \\
\hline Cl8: I cis & 368.8 & 372.2 & 352.0 & 362.8 & 358.9 & 347.0 & 10.54 & 0.548 \\
\hline $\mathrm{C} 18: \ln -9 \mathrm{c}^{3}$ & 346.9 & 350.1 & 330.7 & 342.1 & 336.7 & 322.9 & 10.88 & 0.518 \\
\hline C $18: \ln -7 \mathrm{c}$ & 13.5 & 13.5 & 13.1 & 12.8 & 13.4 & 14.5 & 0.69 & 0.659 \\
\hline C18: $1 \mathrm{n}-6 \mathrm{c}$ & $2.2^{\mathrm{b}}$ & $2.1^{\mathrm{b}}$ & $2.0^{\mathrm{h}}$ & $1.9^{\mathrm{h}}$ & $2.3^{\mathrm{n}}$ & $3.2^{\circ}$ & 0.18 & 0.000 \\
\hline C $18: 1 n-2 t / n-4 c$ & 3.1 & 3.2 & 3.1 & 3.1 & 3.4 & 3.4 & 0.11 & 0.179 \\
\hline C.18:1 trans & 25.2 & 23.7 & 26.2 & 22.8 & 24.7 & 27.7 & 1.58 & 0.339 \\
\hline$C .18: \ln -12 t$ & $4.0^{*}$ & $3.9^{\mathrm{a}}$ & $3.9^{a}$ & $3.6^{\mathrm{ab}}$ & $4.0^{\mathrm{a}}$ & $3.0^{\mathrm{h}}$ & 0.20 & 0.012 \\
\hline C $18: \ln -9 t-n-7 t$ & 20.9 & 19.6 & 22.0 & 19.0 & 20.5 & 24.5 & 1.45 & 0.139 \\
\hline C20: $\ln -9$ & 2.4 & 2.5 & 1.9 & 2.4 & 1.7 & 1.6 & 0.27 & 0.085 \\
\hline polyenoic FA & 102.5 & 97.6 & 113.3 & 112.2 & 109.0 & 124.8 & 13.29 & 0.779 \\
\hline$C: 8: 2 n-6$ & 60.1 & 55.8 & 64.3 & 63.7 & 63.4 & 72.7 & 8.03 & 0.793 \\
\hline C $18: 2$ conjugated & 3.8 & 3.9 & 3.9 & 3.2 & 3.4 & 4.1 & 0.28 & 0.213 \\
\hline $\mathrm{C} 20: 2$ & 1.7 & 1.7 & 2.1 & 2.8 & 2.3 & 2.4 & 0.31 & 0.123 \\
\hline CI8:3n-3 & 6.6 & 6.9 & 6.7 & 6.4 & 6.3 & 6.6 & 0.75 & 0.993 \\
\hline$C 20: 4 n-6$ & 15.2 & 14.7 & 18.3 & 18.3 & 16.9 & 20.2 & 2.44 & 0.624 \\
\hline$C 20: 5 n-3$ & 3.2 & 3.2 & 3.6 & 3.6 & 3.3 & 3.8 & 0.41 & 0.877 \\
\hline$(22: 6 n-3$ & 1.2 & 1.4 & 1.6 & 1.8 & 1.5 & 1.7 & 0.24 & 0.768 \\
\hline
\end{tabular}

1 SEM $=$ standard error of the means. Means by treatment, $n=6$. LS mean values within the sane line sharing no common superscript are significantly different $(\mathrm{P}<0.05)$

2 C 15:0, C17:0 and C 19:0

${ }^{3}$ other $\mathrm{C} 18: 1$ isomers possibly included are $\mathrm{n}-12 \mathrm{c}$ and $\mathrm{n}-6 \mathrm{t}$ to $\mathrm{n}-3 \mathrm{t}$ (Precht and Molkentin, 1995) 
TABLE 5

Fatty acid (FA) composition and melting properties of intermuscular fat ${ }^{1}$

\begin{tabular}{|c|c|c|c|c|c|c|c|c|}
\hline . & $\mathrm{CO}$ & $\mathrm{CS}$ & $\mathrm{CL}_{\mathrm{r}}$ & $\mathrm{CL}_{\mathrm{d}}$ & $\mathrm{CL}_{\mathrm{dh}}$ & $\mathrm{SL}_{\mathrm{d}}$ & SEM & $\mathrm{P}$ \\
\hline \multicolumn{9}{|l|}{ FA profile, $\mathrm{g} / \mathrm{kg}$ total $\mathrm{FA}$} \\
\hline saturated FA & 577.7 & 583.4 & 604.6 & 602.9 & 589.3 & 600.0 & 11.07 & 0.474 \\
\hline $\mathrm{C} 14: 0$ & 22.8 & 22.3 & 21.3 & 21.1 & 22.5 & 19.9 & 1.01 & 0.379 \\
\hline $\mathrm{C} 16: 0$ & 200.0 & 206.2 & 201.1 & 196.8 & 202.8 & 210.3 & 4.37 & 0.348 \\
\hline C18:0 & 331.3 & 331.2 & 356.0 & 356.2 & 335.4 & 344.3 & 10.50 & 0.347 \\
\hline C20:0 & $3.9^{a}$ & $3.8^{\mathrm{a}}$ & $3.5^{\mathrm{ab}}$ & $3.1^{\mathrm{ab}}$ & $2.9^{b}$ & $2.8^{\mathrm{b}}$ & 0.19 & 0.001 \\
\hline odd numbered ${ }^{2}$ & $19.2^{\mathrm{c}}$ & $19.5^{\mathrm{c}}$ & $22.2^{\mathrm{b}}$ & $25.1^{\mathrm{a}}$ & $25.0^{\mathrm{a}}$ & $22.3^{\mathrm{b}}$ & 0.53 & 0.000 \\
\hline monoenoic FA & 396.3 & 391.4 & 371.7 & 375.9 & 386.5 & 375.7 & 11.08 & 0.599 \\
\hline $\mathrm{C} 16: 1$ & 16.2 & 16.5 & 15.7 & 15.7 & 17.7 & 17.8 & 0.82 & 0.275 \\
\hline $\mathrm{C} 17: 1$ & $4.0^{\mathrm{b}}$ & $4.1^{b}$ & $4.2^{\mathrm{b}}$ & $4.7^{\mathrm{ab}}$ & $5.1^{\mathrm{a}}$ & $4.3^{\mathrm{ab}}$ & 0.22 & 0.011 \\
\hline total C18:1 & 371.7 & 366.8 & 348.6 & 352.4 & 360.2 & 350.7 & 10.11 & 0.563 \\
\hline $\mathrm{C} 18: 1 \mathrm{cis}$ & 332.8 & 329.6 & 308.4 & 314.8 & 321.6 & 306.5 & 10.64 & 0.444 \\
\hline$C 18: \ln -9 c^{3}$ & 313.3 & 310.5 & 290.2 & 297.5 & 303.0 & 286.3 & 10.64 & 0.452 \\
\hline $\mathrm{C} 18: \ln -7 \mathrm{c}$ & $9.4^{\mathrm{a}}$ & $9.1^{\mathrm{a}}$ & $8.7^{\mathrm{ab}}$ & $7.9^{b}$ & $8.5^{\mathrm{ab}}$ & $8.9^{\mathrm{ab}}$ & 0.26 & 0.009 \\
\hline$C 18: \ln -6 c$ & $2.5^{\mathrm{ab}}$ & $2.4^{b}$ & $2.2^{\mathrm{b}}$ & $2.1^{\mathrm{b}}$ & $2.5^{\mathrm{ab}}$ & $3.2^{\mathrm{a}}$ & 0.16 & 0.001 \\
\hline $\mathrm{C} 18: \ln -2 \mathrm{t} / \mathrm{n}-4 \mathrm{c}$ & $5.0^{\mathrm{b}}$ & $5.1^{\mathrm{b}}$ & $5.0^{\mathrm{b}}$ & $4.9^{b}$ & $5.1^{\mathrm{b}}$ & $5.8^{\mathrm{a}}$ & 0.12 & 0.001 \\
\hline $\mathrm{C} 18: 1$ trans & 38.9 & 37.1 & 40.2 & 37.6 & 38.6 & 44.2 & 2.79 & 0.526 \\
\hline $\mathrm{C} 18 \mathrm{ln}-12 \mathrm{t}$ & 5.4 & 5.6 & 5.8 & 5.7 & 5.9 & 4.6 & 0.34 & 0.106 \\
\hline $\mathrm{C} 18: \ln -9 \mathrm{t}-\mathrm{n}-7 \mathrm{t}$ & 33.1 & 31.1 & 34.0 & 31.5 & 32.3 & 39.4 & 2.47 & 0.227 \\
\hline$C 20: \ln -9$ & $2.3^{a}$ & $2.0^{\mathrm{ab}}$ & $1.6^{\mathrm{bc}}$ & $1.3^{\mathrm{c}}$ & $1.3^{c}$ & $1.1^{c}$ & 0.10 & 0.000 \\
\hline polyenoic FA & $26.0^{\mathrm{a}}$ & $25.1^{2}$ & $23.7^{\mathrm{ab}}$ & $21.2^{\mathrm{b}}$ & $24.2^{\mathrm{ab}}$ & $24.3^{\mathrm{ab}}$ & 0.77 & 0.006 \\
\hline $\mathrm{C} 18: 2 \mathrm{n}-6$ & $19.4^{a}$ & $18.5^{a}$ & $17.8^{\mathrm{ab}}$ & $16.0^{\mathrm{b}}$ & $18.4^{\mathrm{ab}}$ & $18.4^{\mathrm{ab}}$ & 0.57 & 0.013 \\
\hline C18:2 conjugated & 3.9 & 3.8 & 3.6 & 3.2 & 3.5 & 4.1 & 0.21 & 0.104 \\
\hline $\mathrm{C} 18: 3 \mathrm{n}-3$ & $2.7^{\mathrm{ab}}$ & $2.8^{a}$ & $2.3^{\mathrm{bc}}$ & $2.0^{c}$ & $2.3^{\mathrm{abc}}$ & $1.8^{c}$ & 0.12 & 0.000 \\
\hline \multicolumn{9}{|l|}{ DSC melting properties } \\
\hline onset, ${ }^{\circ} \mathrm{C}$ & -25.5 & -25.5 & -24.6 & -23.5 & -25.1 & -25.2 & 0.53 & 0.104 \\
\hline offset, ${ }^{\circ} \mathrm{C}$ & 55.1 & 55.0 & 55.7 & 56.0 & 56.1 & 56.1 & 0.54 & 0.510 \\
\hline $\operatorname{maximum},{ }^{\circ} \mathrm{C}$ & & & & & & & & \\
\hline peak 1 & 13.4 & 12.5 & 13.2 & 14.1 & 13.0 & 12.9 & 0.34 & 0.059 \\
\hline peak 2 & 46.4 & 46.8 & 47.7 & 47.6 & 47.1 & 47.6 & 0.48 & 0.412 \\
\hline total enthalpy, $\mathrm{J} / \mathrm{g}$ & 103 & 103 & 103 & 104 & 103 & 103 & 1.4 & 0.991 \\
\hline relative enthalpy, \% & & & & & & & & \\
\hline of peak 1 & 53.8 & 5 & 48.4 & 49.6 & 49.9 & 46.0 & 2.02 & 0.196 \\
\hline of peak 2 & 46.2 & 48.3 & 51.6 & 50.4 & 50.1 & 54.0 & 2.02 & 0.196 \\
\hline \multicolumn{9}{|c|}{ percentage of total enthalpy } \\
\hline at $2^{\circ} \mathrm{C}$ & 17.1 & 17.6 & 15.1 & 15.4 & 16.8 & 15.8 & 0.93 & 0.339 \\
\hline at $20^{\circ} \mathrm{C}$ & 48.4 & 48.1 & 43.6 & 45.1 & 46.3 & 43.1 & 1.69 & 0.193 \\
\hline
\end{tabular}

' $\mathrm{SEM}=$ standard error of the means. LS means by treatment, $n=6$. Mean values within the same line sharing no common superscript are significantly different $(\mathrm{P}<0.05)$

$\mathrm{C} 15: 0, \mathrm{C} 17: 0$ and $\mathrm{C} 19: 0$

${ }^{3}$ other $\mathrm{C} 18: 1$ isomers possibly included are $n-12 \mathrm{c}$ and $\mathrm{n}-6 \mathrm{t}$ to $\mathrm{n}-3 \mathrm{t}$ 
TABLE 6

Fatty acid (FA) profile of the kidney fat. $\mathrm{g} / \mathrm{kg}$ total $\mathrm{FA}^{\prime}$

\begin{tabular}{|c|c|c|c|c|c|c|c|c|}
\hline & $\mathrm{CO}$ & CS & $\mathrm{CL}_{\mathrm{r}}$ & $\mathrm{CL}_{\mathrm{d}}$ & $\mathrm{CL}_{\mathrm{d} n}$ & $\mathrm{SL}_{\mathrm{a}}$ & SEM & $P$ \\
\hline Saturated FA & 633.7 & 639.6 & 652.5 & 654.0 & 647.0 & 661.1 & 9.69 & 0.445 \\
\hline $\mathrm{C} 14: 0$ & 25.9 & 26.5 & 24.9 & 26.2 & 28.0 & 25.3 & 1.04 & 0.413 \\
\hline C16:0 & 212.9 & 221.8 & 213.3 & 213.9 & 222.1 & 232.4 & 4.48 & 0.038 \\
\hline C18:0 & 370.3 & 366.4 & 387.2 & 384.3 & 367.1 & 376.5 & 9.96 & 0.570 \\
\hline $\mathrm{C} 20: 0$ & $4.5^{\mathrm{ah}}$ & $4.5^{\prime \prime}$ & $4.1^{\mathrm{ibc}}$ & $3.6^{\mathrm{bc}}$ & $3.4^{i}$ & $3.3^{\circ}$ & 0.21 & 0.001 \\
\hline odd numbered' & $19.2^{\mathrm{c}}$ & $19.5^{\circ}$ & $22.1^{\mathrm{h}}$ & $25.0^{a}$ & $25.3^{a}$ & $22.6^{\mathrm{h}}$ & 0.45 & 0.000 \\
\hline Monoenoic FA & 341.7 & 337.1 & 325.2 & 326.0 & 330.5 & 316.0 & 9.62 & 0.534 \\
\hline C16:1 & 13.6 & 13.9 & 13.4 & 13.8 & 14.9 & 14.5 & 0.81 & 0.772 \\
\hline $\mathrm{C} 17: 1$ & 3.1 & 3.1 & 3.3 & 3.8 & 3.9 & 3.2 & 0.18 & 0.014 \\
\hline total C18:1 & 319.6 & 315.0 & 304.3 & 304.3 & 307.3 & 294.5 & 8.70 & 0.465 \\
\hline Cl8:Icis & 280.5 & 277.6 & 263.8 & 267.2 & 269.3 & 250.5 & 8.52 & 0.226 \\
\hline$C 18: \ln -9 c^{3}$ & 262.2 & 259.8 & 246.8 & 251.0 & 251.8 & 232.1 & 8.54 & 0.223 \\
\hline $\mathrm{C} 18: \ln -7 \mathrm{c}$ & $9.0^{3}$ & $8.5^{\text {sh }}$ & $8.2^{\text {th }}$ & $7.4^{\mathrm{b}}$ & $8.0^{\text {uh }}$ & $8.1^{\text {ah }}$ & 0.28 & 0.023 \\
\hline C18:1n-6c & $2.2^{\mathrm{ab}}$ & $2.1^{\mathrm{dh}}$ & $1.8^{\mathrm{b}}$ & $1.8^{\mathrm{b}}$ & $2.2^{\text {ab }}$ & $2.8^{\mathrm{a}}$ & 0.16 & 0.002 \\
\hline C $18: \ln -2 t / n-4 c$ & $4.7^{b}$ & $4.8^{h}$ & $4.6^{b}$ & $4.8^{\mathrm{b}}$ & $5.0^{\mathrm{sh}}$ & $5.4^{\circ}$ & 0.11 & 0.001 \\
\hline C18:ltrans & 39.1 & 37.3 & 40.5 & 37.0 & 38.0 & 44.0 & 2.53 & 0.394 \\
\hline Cl8: $\ln -12 \mathrm{t}$ & 5.7 & 5.9 & 6.1 & 5.8 & 5.9 & 5.0 & 0.31 & 0.180 \\
\hline $\mathrm{C} 18: \ln -9 \mathrm{t} \cdot \mathrm{n}-7 \mathrm{t}$ & 32.9 & 31.0 & 33.9 & 30.9 & 31.7 & 38.8 & 2.24 & 0.151 \\
\hline C20: $1 n-9$ & $2.1^{14}$ & $1.8^{\mathrm{ab}}$ & $1.4^{\mathrm{bc}}$ & $1.1^{\mathrm{cd}}$ & $1.1^{\mathrm{cd}}$ & $0.9^{d}$ & 0.09 & 0.000 \\
\hline Polyenoic FA & $24.7^{\mathrm{a}}$ & $23.3^{\text {:h }}$ & $22.3^{\text {ih }}$ & $20.0^{h}$ & $22.5^{\mathrm{ab}}$ & $22.9^{\text {ath }}$ & 0.79 & 0.017 \\
\hline C18:2n-6 & $18.8^{\mathrm{a}}$ & $17.6^{\mathrm{ab}}$ & $17.1^{\mathrm{sb}}$ & $15.4^{\mathrm{h}}$ & $17.6^{\mathrm{ih}}$ & $17.8^{\mathrm{ah}}$ & 0.56 & 0.011 \\
\hline C18:2 conjugated & 3.1 & 3.1 & 3.1 & 2.7 & 2.8 & 3.3 & 0.20 & 0.394 \\
\hline C $18: 3 n-3$ & $2.7^{\mathrm{a}}$ & $2.6^{\mathrm{i}}$ & $2.1^{\text {th }}$ & $1.9^{\mathrm{h}}$ & $2.1^{\text {sh }}$ & $1.8^{\mathrm{b}}$ & 0.14 & 0.001 \\
\hline
\end{tabular}

I $\mathrm{SEM}=$ standard error of the means. LS means by treatment, $n=6$. Mean values within the same line sharing no common superscript are significantly different $(\mathrm{P}<0.05)$

$\therefore$ C 15:0, C17:0 and C19:0

3 other C18:1 isomers possibly included are $n-12 c$ and $n-6 t$ to $n-3 t$

canola lecithin was used, and elevated when canola oil and canola seed were fed (significant only in intermuscular fat). In contrast, proportions of $\mathrm{C} 18: 3 \mathrm{n}-3$ were lowest with deoiled canola lecithin and deoiled soya lecithin with significant differences from the canola seed diet in both fats and from the canola oil diet in kidney fat. No significant differences were found in proportions of conjugated linoleic acid (CLA), but in intermuscular fat there was a trend towards higher values for soya lecithin and lower values for the deoiled canola lecithins.

DSC melting properties of intermuscular fat did not show any significant treatment differences (Table 5). With deoiled canola lecithin onset temperature was slightly higher, but offset temperatures and total enthalpy were similar to the other 
groups. All melting profiles had two clearly separated peaks. A trend $(\mathrm{P}<0.1)$ for the maximum of peak 1 ranging at a lower temperature was found for the canola seed diet and for the soya lecithin diet, whereas the maximum of peak 2 was at a similar temperature for all diets. Neither total nor partial enthalpies clearly differed between groups. However, the relative enthalpy of the first peak was numerically highest for the canola oil and seed diet and lowest for the soya lecithin. Vice versa, the relative enthalpy of the second peak tended to be highest for the soya lecithin and lowest for the canola oil and seed diets.

\section{DISCUSSION}

In the present study, virtually no differences were found between the canola oil and the canola seed group, both of which were used as control groups. Previously, equivalence of the effects of unsupplemented and canola seed-supplemented rations in performance and carcass quality of bulls was described using similar types of rations (Sutter et al., 2000). Providing canola oil in an amount of $30 \mathrm{~g} / \mathrm{kg}$ as done in the present study, obviously did not impair rumen digestion to an extent that is typical of oils rich in polyenoic FA (Nagaraja et al., 1997).

The results of the present study indicate that canola lecithins provided in amounts corresponding to $30 \mathrm{~g} / \mathrm{kg}$ diet on a FA basis do not affect growth performance and fecd conversion efficiency when replacing canola oil. Zinn (1989) found that the replacement of yellow grease and blended animal-vegetable-fat by raw soya lecithin had no effect on growth performance of steers either and Mathison (1978) found no significant effect on feed efficiency and carcass characteristics when adding to a steer diet up to $30 \mathrm{~g} / \mathrm{kg}$ of rape seed gum, the non-dehydrated lecithin from the oil refining process. Due to the reason given above, differences between lecithin diets and the oil as well as oilseed diet might have been more pronounced when soyabean oil and whole soyabeans had been used instead of canola oil and seed. Nonetheless, despite its much higher content of polyenoic FA, the use of deoiled soya lecithin also did not impair growth performance and feed conversion efficiency. So this type of lecithin seems to have a reduced efficiency against (fibre) digestion in the rumen which supports the hypothesis of a certain rumen inertness of (deoiled) lecithins. When comparing a diet supplemented with soya lecithin and a diet containing crushed canola seed in lambs. Lough et al. (1991) found higher daily gains with soya lecithin but, like in the present experiment, an equal fecd conversion efficiency due to the simultaneously higher feed and energy intake. The soya lecithin fed lambs expressed a higher dressing percentage than those fed canola seed and the carcasses were fatter (Lough et al., 1991). This is contrary to the present experiment with bulls, where no differences in dressing percentage occurred, and bulls from two lecithin groups, raw canola and deoiled 
soya lecithin, showed a trend towards lower carcass fatness (fatness score, kidney fat proportion, intramuscular fat content).

Increased odd-numbered FA contents in body fats are related to higher microbial activity in the rumen since lipids of rumen microbes have relatively high proportions of odd-numbered FA, which result from FA synthesis starting with propionate (Jilg et al., 1988). The higher proportion of odd-numbered FA found with all canola lecithins suggests that these lecithins did not affect microbial de novo FA synthesis as much as canola oil or seed did. This is partly confirmed by correspondingly somewhat higher concentrations of propionate in rumen fluid at slaughter with the canola lecithins $(9.8 \mathrm{mmol} / \mathrm{l})$ relative to canola oil $(9.1 \mathrm{mmol} / \mathrm{l})$ but not relative to canola seed $(10.8 \mathrm{mmol} / \mathrm{l})$. The intermediate proportion of oddnumbered FA in body tissues found with the use of deoiled soya lecithin suggests that the soya lecithin effects on rumen microbes are slightly higher than those of canola lecithins and slightly lower than those of canola oil. This corroborates with the higher content of polyenoic FA in soya lecithin (Nagaraja et al., 1997). Rumen fluid propionate concentration with deoiled soya lecithin $(10.7 \mathrm{mmol} / \mathrm{l})$ was, however, even slightly higher than with the canola lecithins. Though not significant, the rumen fluid ammonia concentration showed the same trend towards reduced values with lecithins as had been found in vitro (Wettstein et al., 2000), an effect which might be due to the amphiphatic properties of lecithins (Jenkins et al., 1989). These allow the formation of complexes of lecithin and protein, thus possibly reducing protein degradation in the rumen. However, in the present study this did not increase crude protein or absorbable protein utilisation although the contents of calculated absorbable protein were slightly below the recommended allowance. Consequently, it may be concluded that protein was either still not a limiting factor in the metabolism of the bulls or that the protein complex building effect of lecithins was too weak to substantially increase protein flow to the small intestine.

The three fat tissues investigated responded quite similarly to the variation in dietary FA despite the clear general differences in fatty acid composition occurring among them. The reaction was, however, generally more pronounced and alike in intermuscular fat and kidney fat than in intramuscular fat. Generally, in intramuscular fat the amount of intramuscular phospholipids remains quite constant and the proportion of unsaturated FA in the phospholipids is high (Demeyer and Doreau, 1999). Therefore, a low intramuscular FA content coincides with an clevated proportion of unsaturated FA in total intramuscular lipids. This may have masked in part the trend observed in the other body fats.

The ratio of desired CLA to less desired C18:1-trans FA was much lower in body fat of the bulls compared with the ratio found in milk fat when similar types of lecithin were fed to dairy cows earlier (Wettstein et al., 1999). In intramuscular fat the proportion of $\mathrm{C} 18: 1$ trans was less than $2 / 3$ of the C18:1-trans percentage found in the two depot fats. Since the biochemical properties of trans-monocnoic 
FA are more similar to those of saturated FA than to those of cis-monoenoic FA (Precht and Molkentin, 1995) this difference between body fats might be explained by the specific composition of the intramuscular lipids with their high content of phospholipids (Demeyer and Doreau, 1999).

As far as the lipid sources used in this study are concerned, effects on body fat composition were extraordinarily low when whole canola seed replaced canola oil. Obviously, ruminal biohydrogenation of unsaturated FA present in the canola lipids was either generally low or similar in both lipid sources. The latter would question a clear rumen-protective property of the oil when provided together with the seed hulls.

The use of various types of canola lecithins instead of oil also mostly had only weak effects on body fat composition. Despite clear differences in the percentage of several important FA such as C16:0, C18:1, C18:2 and C18:3 between the canola oil and the canola lecithin diets, corresponding alterations in the body fats remained weak or did not exist. In contrast, the lower proportions of C20:0 and C20:1 in canola lecithins compared with the oil were reflected to a certain extent in C20 FA proportion of kidney fat and, to a lower extent, in inter- and intramuscular fat. The values found with canola oil and lecithins in the proportions of the unsaturated FA do not support the hypothesis of a lower ruminal biohydrogenation of the lecithins. The weak trend towards a higher DSC melting onset temperature of intermuscular fat with raw and deoiled canola lecithin relative to the other groups might be explained by the slightly higher content of saturated FA, particularly C18:0. C18:0 was identified to be decisive for the melting properties of bovine fat (Casutt et al., 1999). Accordingly, the slightly lower relative enthalpy of peak 1 in intermuscular fat with the canola lecithins relative to oil might have resulted from the slightly decreased C18:1-cis proportion.

Generally, the clearest effects on body fat composition were found when using deoiled soya lecithin instead of (deoiled) canola lecithin although even these differences were small and far lower than in the feed. As expected from the dietary lipid composition, the proportions of $\mathrm{C} 16: 0$ and polycnoic FA were slightly higher and some C18:1 isomers as well as C20 FA showed a trend towards lower proportions (in part significant) with the use of soya lecithin. Similar effects were reported by Lough et al. (1992) for subcutaneous adipose tissue of lambs with C16:0, C20 and C18:2 when canola seed in feed was exchanged by dcoiled soya lecithin. In contrast, Lough et al. (1992) found higher proportions of $\mathrm{C} 18: 1$ with soya lecithin which might be explained by the associated increase in carcass fatness obscrved with soya lecithin (Demeyer and Doreau, 1999) whereas in the present experiment fatness was not affected by soya lecithin. Using sunflower seed as another source of C18:2 more clearly increased the C18:2 proportion in subcutaneous fat and kidney fat when compared with canola seed (Casutt et al., 2000). 
The higher C18:1n-6-cis proportion presently found with soya lecithin presumably can be explained by the higher content of C18:2n-6 of soya lecithin compared with the canola lecithins since $\mathrm{C} 18: 1 \mathrm{n}-6$-cis is described as a product of biohydrogenation of $\mathrm{C} 18: 2 \mathrm{n}-6$ by certain rumen microbes (Harfoot and Hazlewood, 1997). This also coincides with the slightly higher proportion of C18:1trans FA in intramuscular fat with soya lecithin. Trans FA are formed during biohydrogenation of C18:2 (Harfoot and Hazlewood, 1997). However, the reasons for higher proportions of C18:1n-12-trans with canola lipids instead of soya lecithin (significant in intramuscular fat) remain unclear. Interestingly, the proportion of C18:2 in kidney fat and intermuscular fat was highest with canola oil followed by canola seed and not with soya lecithin as expected from the FA composition of the diet. Therefore the question arises whether canola oil and seed inhibit rumen microbes to a greater extent so resulting in less effective biohydrogenation than with lecithins. This would correspond to the findings of higher proportions of odd-numbered FA with the canola lecithins. However, the differences in fat composition as occurring between the soya lecithin and canola lecithin fed bulls were not high enough to cause significant effects on melting properties of intermuscular fat.

\section{CONCLUSIONS}

The present study demonstrated that, when offered in complete rations to fattening bulls in an amount equivalent on a fatty acid basis, the various tested lecithins allowed a growth performance and carcass composition similar to canola oil and seed. Therefore, it can be assumed that they supply similar amounts of net energy as the corresponding oils when adjusted to the same fatty acid content. Further processing of canola lecithins such as deoiling had only minor effects and seems to be of limited use when lecithins are supplemented at relatively low proportions. On the other hand, deoiling might be a key procedure to avoid adverse effects on rumen fermentation when higher amounts, particularly of soya lecithin, are used. It further remains a matter of conjecture under which conditions lecithins might reduce ruminal protcin degradation and so would be advantageous in protein-limited rations. Furthermore, the results illustrate that the use of any of the canola lecithins remains without major consequences on body fat tissue composition when replacing canola oil. Consequently, when lecithins are supplemented to a low-fat ration, similar effects on depot fat composition as well as on its technological and sensory properties can be expected as with the use of oil or whole crushed canola seed. 


\section{ACKNOWLEDGEMENTS}

We are grateful to Prof. M. Wanner, Institute of Animal Nutrition, Faculty of Veterinary Medicine, University of Zurich, and his laboratory for analyzing the volatile fatty acids, and to Dr. H. Leuenberger and the staff of the ETH research station Chamau for their assistance in performing the experiment. We also acknowledge the help of B. Pineroli in the laboratory and the valuable cooperation of the Zurich slaughter plant, namcly Dr. Lauper, and of Mr. Lanz of Züri Fleisch.

\section{REFERENCES}

Casutt M.M.. Scheeder M.R.L.. Escher F., Dufey P.-A., Kreuzer M.. 1999. Relating texture propertics and composition of bovine fat tissue. Fett-Lipid 101.283-290

Casutt M.M., Scheeder M.R.L., Ossowski D.A., Sutter F., Sliwinski B.J., Danilo A. A., Kreuzer M. 2000. Comparative evaluation of rumen-protected fat. coconut oil and various oilseeds supplemented to fattening bulls. 2. Effects on composition and oxidative stability of adipose tissues. Arch. Anim. Nutr. 53, 25-44

Demeyer D.. Doreau M., 1999. Targets and procedures for altering ruminant meat and milk lipids. Proc. Nutr. Soc. 58, 593-607

DLG (Deutsche Landwirtschaftsgesellschaft), 1997. DLG-Futterwerttabellen Wiederkäuer. $7^{\text {th }}$ Edition. DLG-Verlags GmbH, Frankfurt am Main (Germany)

Drochner W. Heller R., 1996. Neue Ergebnisse zum Einsătz geschützter Fette bei Wiederkäuern. Übers. Ticremähr. 24, 52-61

FAG (Forschungsanstalt für viehwirtschaftliche Produktion), 1994. Fütterungsempfehlungen und Nährwertabellen für Wiederkäuer. $3^{\text {rd }}$ Edition. Landwirtschaftliche Lehrmittelzentrale. Zollikofen (Switzerland)

GSF (Genossenschaft für Schlachtvieh und Fleischversorgung), 1994. Einschätzungssystem für grosses Schlachtvich und Schlachtkälber. Finkenhubelweg 11. CH-3001 Bern (Switzerland)

Harfoot C.G., 1981. Lipid metabolism in the rumen. In: W.W. Christie (Editor). Lipid Metabolism in Ruminant Animals. Pergamon Press, Oxford (UK), pp. 21-55

Harfoot C.G., Hazlewood G.P.. 1997. Lipid metabolism in the rumen. In: P.N. Hobson. C.S. Stewart (Editors). The Rumen Microbial Ecosystem. 2is Edition. Blackic Academic and Professional. London (UK), pp. 382-426

ILPAC (International Union of Pure and Applied Chemistry). 1987. Standard Methods for the Analysis of Oils, Fats and Derivates. $7^{\text {1h }}$ Edition. Blackwell Scientific Publications, Oxford (UK)

Jenkins T.C.. Fotouhi N.. 1990. Effects of lecithin and corn oil on site of digestion, ruminal fermentation and microbial protein synthesis in sheep. J. Anim. Sci. 68, 460-466

Jenkins T.C.. Gimenez T., Cross D.L., 1989. Influence of phospholipids on ruminal fermentation in vitro and on nutrient digestion and serum lipids in sheep. J. Anim. Sci. 67, 529-537

Jilg T. Aiple K.P. Steingass H.. 1988. Fettstoffweclisel und Wirkungen von Futterfetten beim Wiederküuer. Übers. Tieremähr. 16, 109-152

Kreuzer M., Gerhardy H., Ossowski D., Voss, G.E.M.. 1995. Improved storage and dietetic properties of carcass fat tissues in growing Holstein as well as Charolais $\times$ Holstein bulls fed full-fat rapeseed. Arch. Anim. Breed. 38, 163-175 
Lough D.S., Solomon M.B., Rumsey T.S., Elsasser T.H., Slyter L.L., Kahl S., Lynch G.P., 1991. Effects of dictary canola seed and soy lecithin in high-forage diets on performance, serum lipids, and carcass characteristics of growing ram lambs. J. Anim. Sci. 69, 3292-3298

Lough D.S., Solomon M.B., Rumsey T.S., Elsasser T.H. Slyter L.L.. Kah! S., Lynch G.P., 1992. Effects of dietary canola seed and soy lecithin in high-forage diets on cholesterol content and fatty acid composition of carcass tissues of growing ram lambs. J. Anim. Sci. 70, 1153-1158

Mathison G.W., 1978. Rapeseed gum in finishing diets for steers. Can. J. Anim. Sci. 58, 139-142

Nagaraja T.G., Newbold C.J., van Nevel C.J., Demeyer D.1.. 1997. Manipulation of ruminal fermentation. In: P.N. Hobson, C.S. Stewart (Editors). The Rumen Microbial Ecosystem. $2^{\text {nd }}$ Edition. Blackie Academic and Professional, London (UK), pp. 523-632

Naumann K., Bassler R., 1997. Die chemische Untersuchung von Futtermitteln. Methodenbuch. Vol. III. $3^{\text {rt }}$ Edition. VDLUF $\Lambda$-Verlas, Darmstadt (Germany)

Pardun H., 1988. Die Pflanzenlecithine: Gewinnung, Eigenschaften, Verarbeitung und Anwendung pflanzlicher Phosphatidpräparate, Verlag für chemische Industrie H. Ziolkowsky K.G.., Augsburg (Germany)

Precht D., Molkentin J., 1995. Trans fatty acids: implications for health, analytical methods, incidence in cdible fats and intake. Nahrung 39, 343-374

SAS 1996. SAS/STAT User`s Guide: Statistics, Version 6.12, SAS Institute Inc., Cary. VC (USA)

Sutter F. Casutt M.M. Ossowski D.A.. Scheeder M.R.L., Kreuzer M., 2000. Comparative evaluation of various oilseeds, coconut oil and rumen-protected fat in the nutrition of faltening bulls. 1. Effects on growth. carcass and meat quality. Arch. Anim. Nutr. 53, 1-23

Tangerman A.. Nagengast F.M.. 1996. $\Lambda$ gas chromatographic analysis of fecal short-chain fatty acids, using the direct injection method. Anal. Biochem. 236, 1-8

Wettstein H.-R., Machmüller $\Lambda$., Kreuzer M., 2000. Effects of raw and modified canola lecithins compared to canola oil. canola seed and soy lecithin on ruminal fermentation measured with Rumen Simulation Technique. Anim. Feed Sci. Tech. 85, 153-169

Wettstein. H.-R., Sutter, F. Machmüller, A., Schecder, M.R.L., Kreuzer, M., 1999. Effect of partial replacement of rumen-protected fat by various plant lecithins on nutrient digestion and milk composition in dairy cows. In: G. Stone. T.D. A. Forbes, J.W. Stuth. F.M. Byers (Editors). Nutritional Ecotogy of Herbivores. San Antonio. TX (USA)

Yoon C.S.. Jung K.K.. Bae D.H., 1986. Effect of crude soybean lecithin supplementation on the digestibility, rumen and blood fatty acid composition in sheep. Korean J. Anim. Sci. 28 , $488-499$

Zinn R.A.. 1989. Influence of level and source of dietary fat on its comparative feeding value in finishing diets for steers: feedlot cattle growth and performance. J. Anim. Sci. 67, 1029-1037 


\section{STRESTCZENIE:}

Wplyw lecytyn canoli i soi w porównaniu z olejem i nasionami canoli na wyniki produkcyjne, jakość tuszy i skład tłuszczu ciala rosnących buhajów

Opasane buhaje, brunatne szwyce. o początkowej masic ciała $170 \mathrm{~kg}$, żywiono dawkami pasz 7. dodatkiem surowych lub preparowanych (odolejonych lub odolejonych/częściowo hydrolizowanych) lecytyn canoli lub odolejonych lecytyn sojowych w ilości $30 \mathrm{~g} / \mathrm{kg} \mathrm{s.m.} \mathrm{kwasów} \mathrm{tłuszczowych.}$ Porównano je takżc z dawkami uzupełnionymi olejem $z$ canoli lub gniecionymi nasionani canoli.

Nie stwierdzono różnic w przyrostach, wykorzystaniu paszy oraz cechach tusz buhajów z różnych grup żywieniowych. Zwiększony udział kwasów tłuszczowych o nieparzystej liczbie atomów węgla w tłuszczı ciała wskazuje, że lecytyny w mniejszym stopniu mogą wpływać na przebicg fermentacji w żwaczu niż olejc. Tendencja w zmianach stężenia anoniaku w żwaczu sugeruje, że przy podawaniu lecytyn zmniejsza się degradacja białka w żwaczu. Zawartość wielonienasyconych kwasów tłuszczowych w tłuszczu nerkowym i miedzymiçśniowym była najwiçksza przy podawaniu olcju canoli. Profil kwasów tłuszczowych tłuszczu ciała w wiçkszym stopniu zalcżał od pochodzenia lecytyn (canola lub soja) niż pochodzenia oleju lub technologicznej modyfikacji lecytyn.

W podsumowaniu stwierdzono, że lecytynami canoli można zastąpić olcj 7. canoli bez. większego wplywu na wzrost buhajów oraz wydajność rzeżną, i tylko na pewne zmiany w składzie tłuszczu tuszy. 